\title{
FILOZOF DO FILOZOFA. WOKÓŁ LISTU BOLESŁAWA MICIŃSKIEGO DO KS. AUGUSTYNA JAKUBISIAKA*
}

Listy Bolesława Micińskiego stanowią wielką rzadkość. Spuścizna, którą on sam zachował, jest niestety nieduża. Wyjeżdżając z Polski w 1939 r., spalił swoje materiały związane z pracą radiową (MiciŃsKi i STEMPOwsKi 1995, 88). Spora część jego archiwum zaginęła też na skutek zniszczenia mieszkania Micińskich w Warszawie. Burzliwe i krótkie życie autora Portretu Kanta, niespokojne czasy wojny, niekorzystna atmosfera wokół jego twórczości przez powojenne dziesięciolecia czy wreszcie skomplikowane losy adresatów pism - to istotne czynniki wpływające na fakt, że epistolografia tego niezwykłego filozofa i pisarza jest, jak dotąd, mało znana. Tymczasem opublikowane listy świadczą o tym, że to właśnie one były niejednokrotnie dalszym ciągiem jego utworów, dawały bliższy wgląd w jego poglądy, a także niosły wiele informacji biograficznych. Był to bowiem człowiek, który „z niezliczoną ilością ludzi rozmawiał, do niezliczonej pisał listy" (TATARKIEWICZ 1977). W przypadku Micińskiego każdy list jest ważnym tropem na drodze do odtwarzania spuścizny, myśli oraz biografii autora Portretu Kanta. Zachował się jeden list Micińskiego do ks. Augustyna Jakubisiaka. Jego publikacja jest dobrą okazją, aby przybliżyć też postaci obu filozofów i wskazać na to, co ich łączyło.

Dr hab. RYSZARD ZAJĄCZKOwSKI, prof. KUL - Katolicki Uniwersytet Lubelski Jana Pawła II, Wydział Filozofii, Katedra Historii Filozofii w Polsce; adres do korespondencji: Al. Racławickie 14, 20-950 Lublin; e-mail: rzajac@kul.pl. ORCID: https://orcid.org/0000-0003-3417-3666

*Artykuł powstał w ramach grantu Regionalnej Inicjatywy Doskonałości realizowanego przez Wydział Filozofii Katolickiego Uniwersytetu Lubelskiego Jana Pawła II. Za zaproszenie do Paryża bardzo dziękuję Panu Prof. Michałowi Masłowskiemu.

Annie Micińskiej zawdzięczamy pierwsze powojenne wydanie Pism Micińskiego (MıcıŃskı 1970). Tam też po raz pierwszy opublikowano sporo jego listów. Druga duża kolekcja korespondencji to listy B. Micińskiego z Jerzym Stempowskim (Miciński i STEMPOwsKi 1995). 
Bolesław Miciński urodził się 23 kwietnia 1911 r. w Mokrej na Podolu (niedaleko Kijowa), gdzie wówczas mieszkało wielu Polaków. W wyniku rewolucji 1917 Micińscy utracili swój majątek i przez Odessę przedostali się do Polski. Osiedlili się początkowo w Bydgoszczy, gdzie w willi na Bielawkach sąsiadowali z przybyłymi też z tamtych terenów Szymanowskimi, pożyczając kompozytorowi fortepian, którego nie posiadał (KRAUzowa 1979, 211) ${ }^{1}$. W klasycznym gimnazjum młody Miciński zaniedbał przedmioty ścisłe i musiał powtarzać klasę. Rodzice przenieśli go więc do szkoły w Warszawie, tam zaś mógł jeszcze bardziej pogłębiać swoje fascynacje antykiem. Ważnym choć trudnym okresem w życiu młodego Bolesława był roczny pobyt w Zakopanem w 1929/1930 r., gdzie musiał wyjechać na kurację, gdyż niespodziewana choroba płuc wymagała zmiany klimatu. Tam właśnie otrzymał kolejny poważny szlif intelektualny dzięki częstym i bliskim, lecz też burzliwym kontaktom ze starszym od niego o 26 lat Witkacym. W 1931 r. Miciński zaczął studia w Uniwersytecie Warszawskim. Przez rok studiował historię sztuki, a potem przeniósł się na filozofię. Studiując, zajmował się jednocześnie pracą literacką, którą rozpoczął w lewicowo zorientowanej Kwadrydze w 1931 r. Od 1932 r. przez dwa lata był członkiem redakcji czasopisma Zet, a w 1935 r. objął dział krytyki literackiej w endeckim czasopiśmie Prosto z Mostu. Współpracował też z takimi czasopismami jak Pion, Ateneum i Verbum. Był cudownym dzieckiem i duszą towarzystwa. Przyjaźnił się ze wszystkimi. Nie miały dla niego większego znaczenia opcje polityczne. Pracował tam, gdzie mógł rozwijać swój talent. Od 1936 r. w warszawskim mieszkaniu Bolesława i Haliny Micińskich spotykali się ludzie należący do ówczesnej elity intelektualnej ${ }^{2}$. Promotorem jego pracy magisterskiej, obronionej 27 kwietnia 1937 r., był Władysław Tatarkiewicz ${ }^{3}$. Jesienią 1937 r. Miciński wraz żoną

\footnotetext{
${ }^{1}$ Znajomość Bolesława Micińskiego z Karolem Szymanowskim okazała się później, i to $\mathrm{z}$ różnych względów, bardzo ważna dla autora Portretu Kanta.

${ }^{2}$ Tak pisze o tym teściowa Micińskiego, Zofia Krauzowa: „Toteż kiedy młodzi po ślubie [w 1936 r. - R.Z.] zamieszkali na Saskiej Kępie w dwupokojowym mieszkanku na poddaszu, odwiedzając ich w Warszawie miałam szczęście poznać tam niektórych z ich najbliższych przyjaciół i znajomych: niesamowitego Witkacego; poetów - Sebyłę, Czechowicza, Miłosza, Gałczyńskiego; muzyków - Régameya, Spiska, Palestra, Kondrackiego, Maciejewskiego; początkujących podówczas pisarzy - Andrzejewskiego, Brezę, Rudnickiego, Straszewicza, Gombrowicza, Parnickiego; malarzy - Czapskiego, Żuławskiego, Waśkowskiego, Bielską, Ujejskiego, Brandla, ... któż tam nie bywał! Nawet podobno sam stary profesor Zieliński w czarnej pelerynie wdrapał się na ich stryszek. Na soboty i niedziele zapraszani byli Bolkowie do Stawiska do Jarosławowstwa Iwaszkiewiczów, opiekujących się młodymi talentami” (KRAUzowa 1972, 213).

${ }^{3} \mathrm{~W}$ pracach poświęconych Micińskiemu często pojawia się wzmianka, że jego rozprawa magisterska zaginęła. Nie jest to prawdą. Zachowała się ona w nienaruszonym stanie $\mathrm{w}$ jego
} 
wyjechał do Francji w celu zbierania materiałów do doktoratu ${ }^{4}$. Do 5 marca 1938 r. przebywał w uniwersytecie w Grenoble, mając za opiekuna naukowego profesora Jacques'a Chevaliera. Napisał wtedy esej Dyliżans filozoficzny, poświęcony postaci Victora Cousina. Kilka następnych miesięcy przed powrotem do Polski latem 1938 r. Micińscy spędzili w Paryżu, a następnie przez rok Miciński pracował Warszawie w Polskim Radiu, gdzie pełnił funkcję redaktora działu prozy.

Był zatem Miciński krytykiem literackim i dziennikarzem, ale do historii przeszedł głównie jako jeden z pierwszych polskich eseistów, a zwłaszcza autor esejów filozoficznych, który wypracował także model tego gatunku. Bez przesady można go zaliczyć do ścisłego grona eseistów światowych, takich jak Umberto Eco czy José Ortega y Gasset. Będąc pisarzem i filozofem, zdecydowanie przeciwstawiał się temu, co ironicznie określał jako „zjawisko tez doktorskich”. Jak słusznie zauważył profesor Tatarkiewicz, „książka filozoficzna, udokumentowana i kompletna, byłaby wbrew jego naturze" (TATARKIEWICZ 1977, 301). Dzięki temu Miciński stworzył nowy gatunek literacki, w którym zagadnienia filozoficzne były tematem artystycznym, a nie przedmiotem naukowym. Taki charakter mają jego eseje filozoficzne: Podróże do piekiet (1937), Dyliżans filozoficzny (1938) czy uchodzący za arcydzieło gatunku Portret Kanta (1942). Miciński zmarł w Laffrey 30 maja 1943 r. Miesiąc później, 1 lipca 1843 r., w świetlicy „Grand Hotelu” w Grenoble odbył się poświęcony mu wieczór, na którym wspomnienia wygłosili Seweryn Walfisz (zaprzyjaźniony z pisarzem od czasu pobytu w Lourdes były sędzia Sądu Najwyższego RP) i ks. Augustyn Jakubisiak.

O kontaktach Micińskiego i Jakubisiaka pisano niewiele (AMBROŻEwICZ 2003, 87-94). Tymczasem była to relacja bardzo ważna oraz płodna inte-

teczce studenckiej w archiwum Uniwersytetu Warszawskiego (sygnatura akt RP 39196). Liczy 45 stron standardowego maszynopisu. Złożona została w dziekanacie 25 stycznia $1937 \mathrm{r}$. i oceniona przez promotora na „dobry”. Nosi ona tytuł: Rzeczywistość i jej deformacja w sztuce. We wspomnianej teczce zachowały się też m.in. dwa zaświadczenia profesora W. Tatarkiewicza. Pierwsze datowane jest 18 marca 1936 r.: „Stwierdzam niniejszym, że p. Bolesław Miciński otrzymał temat pracy magisterskiej w zakresie filozofii pt. «Deformacja rzeczywistości w utworze literackim». Temat ten został dany p. Micińskiemu do opracowania w roku ak. 1934/35" 19 stycznia 1937 r. profesor W. Tatarkiewicz wystawił drugie zaświadczenie: „Zaświadczam niniejszym, że p. Bolesław Miciński L.alb.39196 złożył mi swą pracę magisterską pt. «Deformacja rzeczywistości w sztuce». Zaświadczenie niniejsze wydane jest celem przedstawienia Komisji Egzaminów Magisterskich”. Siostra Micińskiego, Aniela Micińska, twierdzi, że impulsem do napisania pracy pod takim tytułem była ostatnia rozmowa z Szymanowskim (por. list do J. Stempowskiego z 3 lutego 1944, s. 321).

${ }^{4} \mathrm{~W}$ tym czasie wspomniane mieszkanie Micińskich zajmował Czesław Miłosz. 
lektualnie i duchowo - zwłaszcza dla tego pierwszego ${ }^{5}$. Jakubisiak, starszy od Micińskiego o 27 lat, znacznie oddziałał na niego zarówno jako filozof, jak też duszpasterz, dlatego zapewne nie przypadkiem jemu właśnie młody warszawski filozof zadedykował Portret Kanta. Kim był ten dziś prawie zupełnie (choć niesłusznie) zapomniany duchowny i myśliciel? ${ }^{6}$ Urodził się 28 maja 1884 r. W Warszawie, gdzie ukończył też szkołę średnią i seminarium duchowne. Święcenia kapłańskie otrzymał w wieku 22 lat. Początkowo pracował jako wikariusz w Piątku Kaliskim, w Mińsku Mazowieckim i w Łodzi. Chciał jednak przede wszystkim poświęcić się pracy naukowej w dziedzinie filozofii. Podobno zatarg $\mathrm{z}$ policją rosyjską $\mathrm{z}$ powodu udzielenia chrztu dziecku z rodziny prawosławnej przyśpieszył jego decyzję o wyjeździe na studia do Paryża. Przybył tam w 1910 r. i już dwa lata później uzyskał doktorat na podstawie rozprawy Principes de la morale d'après August Cieszkowski. W tym samym roku wystąpił na Sorbonie z wykładem L'influence de Hegel sur la philosophie polonaise. W latach 1912-1914 studiował na Sorbonie matematykę, chemię i fizykę, gdyż znajomość tych nauk uważał za konieczną dla badania zagadnień bytu i jego poznawalności. Uczęszczał też na wykłady Bergsona i zgłębiał myśl Hoene-Wrońskiego, w tym zwłaszcza jego koncepcję Absolutu, poznania, istnienia, czasu i przestrzeni. W 1915 r. ks. Jakubisiak został mianowany kapelanem jeńców polskich z zaboru niemieckiego i austriackiego wcielonych do wrogich im armii. Przez cały okres działań wojennych objeżdżał obozy jenieckie rozrzucone po Francji i wespół ze swoim bratem Stanisławem (profesorem biologii, zamieszkałym po wojnie w Poznaniu) wydawał pismo Jeniec Polak. Do kraju wrócił wraz z armią gen. Hallera. Już jednak w 1920 r. ponownie wyruszył do Paryża, gdzie został prêtre auxiliare w kościele St. Médarda przy ulicy Mauffetard, nie porzucając pracy naukowej. W 1926 r. rząd francuski mianował go kapelanem wszystkich więzień w departamencie Seine. Wykładał w Instytucie Polskim w Paryżu, w Kolegium Francuskim oraz na Sorbonie. Obowiązki duszpasterskie we Francji łączył z corocznymi wizytami w Polsce, gdzie w różnych miastach występował $\mathrm{z}$ wykładami. (Za swoją działalność naukową i duszpasterską został w 1935 r. odznaczony przez rząd polski Złotym Krzyżem Zasługi). W 1937 r. wygłosił też na Sorbonie cykl prelekcji pt. Vers la Causalité Individuelle. Ujawnił się $\mathrm{w}$ nich jako przeciwnik determinizmu i przypadku,

\footnotetext{
${ }^{5}$ Pisała o tym Halina Micińska-Kenarowa w niedokończonym eseju pt. Ksiądz (MicińsKAKenarowa 2003, 241-248).

${ }^{6}$ Wstępny i syntetyczny zarys aktualnego stanu badań nad spuścizną ks. A. Jakubisiaka przedstawił Barłomiej K. Krzych (KrzYch 2018, 113-125).
} 
a zarazem zwolennik przyczynowości wewnętrznej, wyrosłej z wolnej woli i z wolnego, ogólnego, a więc determinującego szczegóły, wyboru jednostki. W roku akademickim 1939/1940 wykładał filozofię na Uniwersytecie Polskim Zagranicą (w Paryżu) i przygotowywał pierwszy numer przeglądu filozoficznego, któremu nadal tytuł La Pensée Antitotalitaire. Czasopismo miało się ukazać 15 czerwca 1940 r. Choć zostało wydrukowane, to jednak drukarnia zniszczyła cały nakład, gdy 9 czerwca Niemcy wkroczyli do Paryża. We wrześniu tegoż roku Jakubisiak opuścił stolicę Francji i osiedlił się w Grenoble, gdzie rozwijał działalność duszpasterską i edukacyjną. W tamtejszym „Grand Hotelu” (w którym początkowo przebywał Miciński z rodziną), gdzie został założony przez PCK dom pracy twórczej dla polskich inteligencji emigracyjnej, ks. Jakubisiak pełnił obowiązki kapelana oraz prezesa komisji naukowej. Organizował oraz zagajał odczyty z zakresu filozofii, historii, polityki i ekonomii. W Grenoble był też prawie jedynym redaktorem 111 numerów Żywego Dziennika. Często zabierał głos na tematy naukowe i polityczne w okolicznościowych przemówieniach i kazaniach ${ }^{7}$. W 1943 ks. Jakubisiak opuścił stolicę departamentu Isère, gdy wkroczyli do niej Niemcy, i osiedlił się we wsi Biviers, gdzie żyła grupa Polaków, m.in. płk. Józef Jaklicz, szef Polskiej Organizacji Wojskowej i ewakuacji przez Pireneje. Pod koniec 1944 r. został mianowany Delegatem Ministerstwa Wyznań Religijnych i Oświecenia Publicznego, w związku z czym przez kilka miesięcy opiekował się polskimi naukowcami i artystami, jak również młodzieżą akademicką, która w tym czasie opuszczała obozy niemieckie i przejeżdżała przez Paryż. W czerwcu 1945 r. wygłosił odczyt w Instytucie Francuskim, po którym zaproponowano mu tytuł członka Académie des Sciences Morales et Politiques (membre correspondant). Nominację miał otrzymać w grudniu. Zmarł jednak nagle 23 listopada 1945 r. w Paryżu.

Zainteresowania naukowe ks. Jakubisiaka obejmowały metafizykę, teorię poznania, etykę i teologię moralną, filozofię polityki oraz historię filozofii polskiej. Pierwszą ogłoszoną pracą naukową Jakubisiaka była rozprawa pt. Podstawy krytycyzmu - rozbiór krytyczny (Warszawa, 1920), którą poświęcił krytyce filozofii Kanta. Jego fundamentalna rozprawa nosi tytuł Essai sur les limites de l'Espace et du Temps (Par Alcan, 1927) ${ }^{8}$. Inne jego

\footnotetext{
${ }^{7}$ Część jego wystąpień z tego okresu została zebrana w książce Wytrwać by zwyciężyć. Zbiór odczytów i przemówień 1940-1945 (Paryż, 1946).

${ }^{8}$ Praca ta została nagrodzona przez Akademię Francuską w 1928 r. Chciał ją przedstawić w Uniwersytecie Warszawskim jako swą rozprawę habilitacyjną, ale nie została przyjęta, ponieważ — jak brzmiała oficjalna odpowiedź z uczelni — nie była napisana po polsku.
} 
ważniejsze prace to: Sur le fondement philosophique du communisme (Paris, 1932), La Pensée et le Libre Arbitre (Paris, 1936), Od zakresu do treści (Warszawa, 1936), Vers la Causalité Individuelle (Paris, 1947). Przebywając w Biviers, napisał też książkę z zakresu teologii moralnej pt. Nowe Przymierze (Paryż, 1948) ${ }^{9}$, w której dał biblijny komentarz do wezwań z Ojcze nasz.

Pierwsze spotkanie Micińskich z ks. Jakubisiakiem tak relacjonuje Halina Micińska-Kenarowa:

Poznaliśmy go w Paryżu w 1937/1938 r. u profesora Zygmunta Zaleskiego, któremu poszliśmy złożyć wizytę jako studenckie małżeństwo przebywające na studiach we Francji. Tam też Ksiądz Jakubisiak zachęcił nas do uczęszczania na Msze w ,jego" kościele St. Medarda, gdzie byliśmy ze trzy razy. Wreszcie jedna wizyta u niego w domu na 20 bis rue Censier na piątym (chyba) piętrze, skąd roztaczał się ponad dachami Paryża rozległy widok aż po Jardin de Plantes. Nie pamiętam, o czym wówczas mój mąż z Księdzem rozmawiali — zapewne o filozofii? ... [...] Kilka zaledwie tych spotkań paryskich z Księdzem wywarło jednak na moim mężu głębokie wrażenie, a szczególnie spowiedź w kościele St. Medard bardzo go wspomogła w ciężkich duchowych rozterkach, które wówczas przeżywał. (Pisał później w jednym z listów do dr. Golonki, że był bliski utopienia się w Sekwanie). (MicińsKa-Kenarowa 2003, 244-245) ${ }^{10}$

Ciekawe, że zupełnie inne okoliczności pierwszego spotkania z Micińskim podaje ks. Jakubisiak:

Bolesława Micińskiego poznałem po raz pierwszy na odczycie moim w roku 1938 w Bibliotece Polskiej w Paryżu. W odczycie tym zatytułowanym Du réel par la

\footnotetext{
${ }^{9}$ Książkę tę zaczął pisać we wrześniu 1942 r. w La Borie w domu ministra Franciszka Puławskiego.

${ }^{10}$ Przyjazd Micińskich do Paryża w marcu 1938 r. poprzedziła krótka wymiana listów z profesorem Zaleskim, wykładowcą języka i literatury polskiej na paryskich uczelniach. Z korespondencji tej (zachowanej w archiwum profesora Zaleskiego w Bibliotece Polskiej w Paryżu) wiadomo, że Micińscy po przybyciu do Paryża 5 marca 1938 r. zamieszkali w Ognisku Polskim pod adresem 15 rue Lamandè. Na sobotę 12 marca o godz. 21 zostali zaproszeni do domu profesora przy 59 rue Boissière. Wtedy właśnie doszło do ich pierwszego spotkania z ks. Jakubisiakiem, $\mathrm{z}$ którym profesor Zaleski był bardzo zaprzyjaźniony. Podobna informacja znajduje się w liście Anieli Micińskiej do Jerzego Stempowskiego. Micińska wspomina, że po przybyciu z Grenoble do Paryża „Bolek przebywa [...] ostry kryzys światopoglądowy; pomaga mu z niego wyjść ostatni - po Witkacym i po Panu - «mistrz duchowy» Bolka, ksiądz Augustyn Jakubisiak; pierwsze z nim paryskie spotkania Bolek zawsze wspominał ze wzruszeniem i wdzięcznością". (Micińska-Kenarowa 1995, 325). Niezwykły wpływ ks. Jakubisiaka na ludzi, z którymi się spotykał, potwierdza jego bliska współpracowniczka Irena Gałęzowska: „Ksiądz Jakubisiak to nie tylko wielki umysł, to również wielkie, gorące serce, pełne miłości bliźniego, gotowe służyć każdemu potrzebującemu radą, pomocą, pociechą. [...] ludzie przychodzący do niego przytłoczeni niepewnością, przygarbieni od smutku, wychodzili śmiało, prosto, gotowi do podjęcia trudów życia" (GAŁĘZOWSKA, 1947, 3).
} 
formalisme intelectuel, występowałem ostro przeciw modnej, zwłaszcza u nas w Polsce, i, moim zdaniem, wysoce szkodliwej dla rozwoju myśli tendencji filozoficznej, ograniczającej treść wypowiedzeń ludzkich, sztucznymi, ad hoc wymyślonymi wymaganiami formy [...]. Byłem wielce zdziwiony wrogim do nich stosunkiem świeżego absolwenta Uniwersytetu Warszawskiego, jakim był wówczas Bolesław Miciński. „Litera usiłuje zabić ducha” - powiedział mi on wówczas, wykazując głębokie zrozumienie tej „nowej”, rzekomą naukowością okrywającej się filozofii. (JAKUBISIAK 1947, 26)

Różnice relacji o pierwszym spotkaniu ks. Jakubisiaka i Micińskiego mogą wynikać z rożnych przyczyn. W świetle zachowanych dokumentów bardziej wiarygodna wydaje się pierwsza wzmianka, nie można jednak zupełnie lekceważyć tego, co zawarte jest w drugiej. Należy pamiętać, że Stowo wstępne x. A. Jakubisiaka do esejów Micińskiego rządzi się swoistą poetyką, w której nacisk pada na wydobycie powinowactw intelektualnych, prezentację poglądów filozoficznych Jakubisiaka i Micińskiego, jak również próbę interpretacji eseistyki filozoficznej autora Portretu Kanta. Z tej ostatniej racji wypowiedź ta jest szczególnie interesująca. Czy Miciński od wiosny 1938 r. stał się uczniem Jakubisiaka? Twierdząco na to pytanie odpowiada Konstanty Régamey. Jego zdaniem od tego czasu Micińskiego „z depresji moralnej ratuje [...] kontakt z ks. Augustynem Jakubisiakiem, którego wplyw na światopoglad filozoficzny Micińskiego jest odtad bardzo wyraźny" (RÉGAMEY 1995, 38-39; wyróżnienie R.Z.). W szkicu o Stempowskim Halina Micińska-Kenarowa dodaje z kolei, że polski duchowny był:

amounier des prisons, słynnym spowiednikiem i łowcą dusz oraz oryginalnym i głębokim filozofem. Jego leibnicjańsko-woluntarystyczne poglądy zawarte w dziele La pensée et la libre arbitre były bliskie Micińskiemu, a głównie fascynowała go osobowość księdza, rozżarzona wewnętrznym ogniem wiary w duchu augustiańskim [...]. W 1939 roku ksiądz odwiedzał swoją rodzinę w Poznaniu i na kilka dni zajrzał do Warszawy, gdzie Miciński zorganizował mu odczyt na Uniwersytecie. (MicińsKa-Kenarowa 1995, 20)

Ten ostatni, z pozoru drobny fakt jest o tyle ważny, że w latach trzydziestych „cała humanistyka na Uniwersytecie Warszawskim była przesiąknięta duchem ateizmu". Wśród słynnych profesorów swoistym wyjątkiem był Władysław Tatarkiewicz, „który bodaj jedyny chadzał z żoną w niedzielę do kościoła, a w nauczaniu stosował tolerancyjny pluralizm" (MicińsKA-KenARowa 2003, 45-46). Miciński, decydując się na zorganizowanie wykładu ks. Jakubisiaka, który od ukazania się książki Od zakresu do treści musiał mieć negatywną 
opinię w warszawskim środowisku naukowym, dał wyraz nie tylko swojej odwagi intelektualnej, lecz także przekonania odnośnie do głoszonych przez duchownego poglądów i jego postawy światopoglądowej.

Gdy po wybuchu wojny Micińscy z obawy przed represjami wyjechali z Warszawy do Wilna, ks. Jakubisiak przesłał im wizy francuskie. Ponieważ otrzymali też (zupełnie nieoczekiwanie) pieniądze na podróż, wkrótce mogli wyruszyć do Francji ${ }^{11}$. W Paryżu 21 grudnia 1939 r. przyszła na świat ich córka Anna Ludwika (ochrzczona zaraz po urodzeniu, ale namaszczona olejami dwa lata później przez ks. Jakubisiaka). W lutym 1940 r. Micińscy (wraz z siostrą Haliny Anielą) zamieszkali w Montaigut en Combrailles w Owernii, $60 \mathrm{~km}$ na południe od Vichy ${ }^{12}$. (W tym czasie byli też często gośćmi w Chateau du Colombier, posiadłości Kazimierza i Feliksy Kranców). Wkrótce jednak musieli zmienić miejsce pobytu. „Po klęsce majowej 1940 roku garstka inteligencji twórczej, która nie dotarła w porę z Paryża do Bordeau, aby zabrać się wraz rządem polskim do Londynu - dążyła w popłochu na południe, na granicę hiszpańską i znalazła się w Lourdes" (MicińsKa-Kenarowa 2003, 231). Pobyt tam nie był długi, m.in. z uwagi na wysokie ceny zakwaterowania. Micińscy wrócili do Colombier, potem przenieśli się do schroniska dla polskiej inteligencji w „Grand Hotelu” w Grenoble. Następnie z powodu choroby Micińskiego musieli zamieszkać $\mathrm{w}$ wiosce o nazwie Bouquéron, a na koniec na farmie w położonym w górach Laffrey, gdzie Miciński zmarł (tam również ma swój grób).

Miciński, odkąd poznał ks. Jakubisiaka, zafascynował się jego stylem myślenia. Łączyło ich krytyczne stanowisko wobec neopozytywizmu Koła Wiedeńskiego z jego materializmem, scjentyzmem i sceptycyzmem. W pracy Od zakresu do treści (1936) ks. Jakubisiak podobny styl filozofowania przypisywał też (niesłusznie) szkole lwowsko-warszawskiej (czemu przeciwstawiał się Łukasiewicz). Twierdził mianowicie, że filozofowie wywodzący się z tych szkół, walcząc z mistyką i próbując zarysować racjonalny obraz rzeczywistości, faktycznie ją zubożają. Z kolei tworząc jednolity język

${ }^{11}$ O niezwykłych o okolicznościach podróży z Wilna do Paryża przez Sztokholm pisze Micińska-Kenarowa w eseju Nieopracowany scenariusz ,filmu akcji” (MicińsKA-KenAROwA 2003, 131-147).

${ }^{12}$ W liście do Jerzego Stempowskiego Miciński pisał: „Za parę dni instalujemy się w malutkim prześlicznym miasteczku w Owerni - Montaigut. Dzięki niesłychanej dobroci Kazia Kranca i jego żony, instalujemy się przyzwoicie. [...] Okolica przepiękna. O $15 \mathrm{~km}$ mieszkają Krancowie w ślicznym «château». Jest piękna kolekcja Bachów. Wysokość $630 \mathrm{~m}$., powietrze cudowne" (Miciński i Stempowski 1995, 67-68). Micińscy mieszkali wówczas pod adresem: Montaigut (en Combraille) Puy de Dome, chez M-me Berthon Peynet. 
naukowy, ograniczają spontaniczny rozwój nauki. Ks. Jakubisiak wydał zatem walkę aprioryzmowi w teorii poznania oraz tezie o ciągłości i zmienności rzeczy. Był przeciwnikiem filozofii odwołującej się do apriorycznych wyobrażeń przestrzeni i czasu, teorii ciągłości i filozofii rozwoju (ewolucji). Zgadzał się $\mathrm{z}$ postulatem stałości bytów w czasie oraz ich nieciągłości w przestrzeni; głosił względność zmiany i ruchu. Powołując się na teorię kwantów, twierdził, że nieciągłość wprowadza sam upływ czasu. Uważał też, że teoria względności zadaje cios klasycznej teorii transformizmu, gdy głosi, że upływ czasu nie jest jednostajny dla wszystkiego i dlatego nie można mówić o jedności powszechnego procesu rozwoju. Złudzenie stawania się (rozwoju) ks. Jakubisiak wiązał z brakiem proporcji między rzeczywistością a możnością (zdolnością) zasięgu naszych zmysłów. Uzasadniał to w następujący sposób:

Nie mogąc zauważyć wszystkich faktów naraz, uwaga ogląda je jedne po drugich. A więc na samym progu świadomości zaczyna się zmiana faktów jednoczesnych na następcze: niemożliwość przekroczenia naraz progu świadomości przez te wszystkie fakty stwarza dla każdego z nas konieczność postrzegania ich $w$ następstwie to znaczy pod postacią czasu. (JAKUBISIAK 1928?, par. 86, 96; wyróżnienia R.Z.)

Nieco dalej zapisał ważną myśl:

Ta właśnie czynność uwagi, biegnącej z powodu swej niedoskonałości po różnych częściach pola świadomości, jest jedyna podstawą naszej idei czasu i jego podziału. (JAKUBISIAK 1928?, par. 86, 97).

Pozór czasu wynika z naszej niemożliwości notowania naraz faktów, napływających do progu świadomości, faktów zarówno zewnętrznych, jak i wewnętrznych, podczas gdy pozór ruchu miejscowego wynika z naszej niemożności uchwycenia wrażeń, które przychodzą z zewnątrz (JAKUBISIAK 1928?, par. 86, 133). Dane zmysłowe są niewyraźnie i niedokładne. Wyjaśnienie doświadczalne chwyta tylko niektóre szczegóły. Wbrew pierwotnym prawom ukazują one byt konkretny jako całkowicie zmienny. Samorzutnie postrzeganie i ruch miejscowy stwarza pozór ciągłości. Ciągłość przestrzeni to nieunikniony skutek naszego niezupełnego postrzegania przestrzenności rzeczy. Dlatego „zmiana, ruch i ciągłość jest tylko skutkiem częściowego i zamazanego poznawania bytu przez nasze zmysły" (JAKUBISIAK 1928?, par. 134, 166). Granice naszych przestrzennych organów i bardzo ograniczony zasięg naszej uwagi są subiektywnym powodem notowania częściowego, a przez to kolejnego obszaru dostępnego postrzeganiu (JAKUBISIAK 1928?, par. 99, 117). 
Czas zatem istnieje zatem tylko w świadomości, a nie poza nią. Nie można dowieść istnienia czasu obiektywnego. Nie ma dowodu na zmianę zachodzącą $\mathrm{w}$ istnieniu naszym lub otaczających nas bytów. Ruch z kolei to „szereg odczuć mięśniowych, które po sobie następują i łączą, ruch świadczy tylko o stykaniu się z sobą własnych elementów składowych" (JAKUBISIAK 1928?, par. 112, 131). Istnienie ogarnięte przez inteligencję bada całość, układ konkretnego istnienia. Okazuje się ono wtedy bez śladu zmiany jako nieciągłe.

Miciński odkrywał u Jakubisiaka przede wszystkim własne pomysły estetyczne, które już wcześniej znalazły wyraz w Podróży do piekiet (1936) w eseju zaskakująco łączącym rożne postaci i epoki. Dlatego z satysfakcją pisał 3 września 1940 r. do Wacława Grzybowskiego (poznanego w Lourdes byłego ambasadora RP w Moskwie):

Teraz zaczynam wolno dochodzić do zrozumienia rozprawy Jakubisiaka o granicach przestrzeni i czasu. Cóż to za epik! Epik filozoficzny - epik przede wszystkim.[...] Jakubisiak w swojej koncepcji czasu jest epicki nie jest homofoniczny, ale polifoniczny, przyjmuje współistnienie wątków historycznych. W jego wizji historycznej jest aktualnie istniejący Pitt i cesarz Aleksander, i Czartoryski, i Churchil, i Stalin i Pan, Panie Ambasadorze. (Miciński 1970, 472; wyróżnienia R.Z.) ${ }^{13}$

To zatem, co Jakubisiak próbował dowodzić na gruncie epistemologicznym, Miciński niezależnie wyeksponował na sposób literacki. Świadczy to o tym, jak głęboko żywioł filozoficzny wszedł w tkankę jego eseistyki zwłaszcza od 1938 r. W uwagach $Z$ notatnika zapisał:

Pokazałem Kanta [Portret Kanta - R.Z] i byłem zachwycony tym, że ksiądz Jakubisiak widział go takim jak go studiował - a przecież nie była to analiza filozoficzna. To zagadnienie formy jest bardzo doniosłe, bo jest — jak mi się zdaje odrębnym aspektem poznawczym. Nie jest to nowością. Pierwsze traktaty filozoficzne były — jak wiemy — rymowane. Z wolna dopiero filozofia wyrzekła się swojej autonomii wyrazu i popadła w nieznośny szablon, niemal totalistyczny uniformizm. (MicIŃsKi i SteMPOWSKI, 1995, 196)

${ }^{13}$ Ten sam wątek Miciński rozwinął w liście do J. Stempowskiego, pisanym również we wrześniu 1940 r.: „Często myślę teraz o teorii czasu ks. Jakubisiaka wyłożonej w jego pracy o granicach przestrzeni i czasu. Czas nie istnieje, czas jest tylko formą pojmowania - rzeczywiście istniejącej przestrzeni. Wszystko - jeśli się tak właśnie można wyrazić — już się stało. Wszystko już się «spełniło». Jakubisiak jest więc epikiem i operuje malarską koncepcją życia. W ramach jego obrazu zawarta jest implicite sprawa predestynacji — problem „pozorny”. Cóż na teraz pozostaje? Możemy tylko oglądać malowidło. Przeważa tu jak w obrazach Józia Czapskiego, czerwień, krwista czerwień” (MiciŃSKi i STEMPOwSKi 1995, 529; wyróżnienia R.Z.). 
Teksty z okresu wojny zawierają uderzające podobieństwa myśli Micińskiego $\mathrm{z}$ tezami o charakterze moralnym zawartymi w pracach ks. Jakubisiaka. Chodzi zwłaszcza o jednostkowość i autodeterminizm.

Po pierwsze zatem u Jakubisiaka i Micińskiego zaznacza się wyraźne dowartościowanie jednostki w obliczu wszystkiego, co może jej zagrażać, zwłaszcza wszelkich totalizmów. Na niepowtarzalność jednostki zorientowany jest katolicyzm, odwołujący się do konkretnej oraz indywidulanej ofiary Jezusa. Autor Nowego Przymierza winił idealizm niemiecki i jego owoc, jakim był marksizm, za zbudowanie filozoficznych podstaw niszczenia wolności jednostki oraz wprowadzania amoralizmu (jak choćby w marksizmie, który zawiesił obowiązywanie etyki związanej ze zwalczanym ustrojem). Podobnie bowiem jak neopozytywizm (z jego materializmem i scjentyzmem) tak samo idealizm przeczy wewnętrznej wolności jednostki i wystawia ją na łup determinizmów. Zwłaszcza $w$ pracach $z$ lat trzydziestych ks. Jakubisiak zaczął rozwijać zagadnienie jednostki i autodeterminizmu. Przyznawał prymat jednostce ludzkiej rozumianej po chrześcijańsku:

[...] jednostce jako takiej, to znaczy jako pochodzącej od Boga, nie zaś jako należącej do tej czy innej grupy ludzi. Mówiąc językiem Arystotelesa, ale wbrew jego filozofii, która dotychczas mąci pojęcia wśród chrześcijan, jednostka ludzka ma nieocenioną wartość jako indywiduum, czyli ze względu na to, co w niej szczególne, jedyne i niezamienne, a nie jako osoba, czyli z powodu tego, co w niej jest ogólne, wspólne z innymi ludźmi i zamienne. (JAKUBISIAK 1948, 264)

Ks. Jakubisiak podkreślał że „wszelką naprawę bytu ludzkiego należy zaczynać od udoskonalenia jednostki" (JAKUBISIAK 1948, 280). Wskazywał też na chrześcijański sens indywidualnego powołania jednostki, polegającego na swobodnej realizacji jej najlepszych wewnętrznych możliwości. W rozprawie z 1937 r. pt. Określenie pojęcia dobra moralnego pisał:

Życie ludzkie, choćby najbardziej szare, nieznane, ma z punktu widzenia chrześcijańskiego nieskończoną wartość i cenę, jako że człowiek każdy jest stworzony na podobieństwo samego Boga, i to Boże odbicie wyrażone jest w nim w sposób jedyny i niepowtarzalny. (JAKUBISIAK 1948, 84)

Metafizyczne bogactwo i niepowtarzalność jednostki - to wątek, który przewija się niemal we wszystkich pracach autora Nowego Przymierza. Ten właśnie aspekt myślenia o antropologicznego odkrywa i pogłębia ks. Jakubisiak, dokonując interpretacji Portretu Kanta: 
Na próżno szukalibyśmy w Portrecie Kanta tych czy innych szczegółów doktryny królewieckiego filozofa: nie ma tam ani wzmianek o sądach syntetycznych a priori, ani o przeciwstawieniu noumenów fenomenom. Znajdujemy tam natomiast cały szereg szczegółów nieznanych ogółowi faktów z codziennego życia twórcy aprioryzmu, charakteryzujących stosunek jego do ludzi, do zwierząt, do ptaków i drzew. Z tych „drobiazgów” pomijanych i niedocenianych przez historyków największego filozofa Niemiec, Miciński odtwarza postawę jego ducha, a więc rzecz najważniejszą nie tylko u Kanta, ale u każdego człowieka. W podobny sposób naszkicowany jest portret Juliana Apostaty. (JAKUBISIAK 1947, 13)

W interpretacji ks. Jakubisiaka Miciński jawi się zatem jako bardzo głęboki eksplorator tajników osoby, którego fascynowały: „[...] bogactwo każdego wnętrza - 'otchłań osobowości', nieświadomość sił skłębionych w człowieku” (JAKUBISIAK 1947, 32). Nie jest to tylko ktoś zafascynowany freudyzmem, ale przede wszystkim tropiciel tego co w człowieku nieuchwytne za pomocą medycznych czy psychologicznych analiz - pisarz tajemnicy człowieka.

Z kolei antropologiczne i eschatologiczne wątki refleksji ks. Jakubisiaka Miciński podjął w eseju O nienawiści, okrucieństwie i abstrakcji (1940). Już sam tytuł wydobywa pojęcia poddane największej krytyce przez ks. Jakubisiaka:

Powtórzmy więc: wojen nie prowadzi się ani o zboże, ani o naftę — nafta jest tylko koniecznym, potężnym środkiem w wojnie, która toczy się o taki a nie inny pogląd na świat, o taką a nie inną koncepcję życia. W przemianach dziejowych, w które zostaliśmy uwikłani, odsłoniło się teoretyczne podłoże walk gospodarczych i zbrojnych. Jesteśmy uwikłani w wojnę, która toczy się między rzeczywistością i abstrakcją — między jednostką a zbiorowością. I dlatego ta wojna jest tak okrutna. I dlatego tak ważna. Bo tylko jednostka jest rzeczywista, tylko jednostka jest nieśmiertelna — tylko przed nią otwarta jest wieczność. Zbiorowość — rasa, naród, klasa - może być długowieczna, nigdy wieczna. Dzieje każdej zbiorowości kończą się u wrót doliny Jozafata. (MiciŃSKI 1970, 142)

W powyżej zacytowanej wypowiedzi Miciński polemizuje zatem — podążając za ks. Jakubisiakiem - z intelektualnym unitaryzmem i determinizmem, które jednostkę czynią mało istotnym przedmiotem gry różnych zbiorowości. Na skutek tego pojawia się też totalitaryzm. Wspomniane zbiorowości będą dlatego podlegały osądzeniu za podeptanie godności i niepowtarzalności jednostki - stąd wzmianka o dolinie Jozafata, czyli przestrzeni sądu.

Druga istotna zbieżność myśli Micińskiego i ks. Jakubisiaka zawiera się $\mathrm{w}$ pojęciu autodeterminizmu. Ks. Jakubisiak poszukiwał tego, co w jedno- 
stce stanowiło jej istotną wielkość i wartość. Stał na gruncie indywidualizmu chrześcijańskiego wywiedzionego z objawienia. Broni wolności ludzkiej woli jako daru Bożego. Jako zdecydowany przeciwnik determinizmu przyznawał ludzkiemu bytowi absolutną autonomię i wolność, która działa stale w przyjętym uprzednio kierunku. Przeciwstawiał się pozytywistycznej tezie o absolutnej wyższości społeczeństwa nad jednostką. Takie myślenie negowało bowiem istnienie osobowego Boga różnego od świata, jednostkowej duszy i jej powołanie do życia wiecznego. W rozprawie Autodeterminizm z $1943 \mathrm{r}$. (ukończonej 29 listopada 1943 r. w Biviers i włączonej do Nowego Przymierza) polski duchowny streścił swoje poglądy z zakresu antropologii filozoficznej. W autodeterminizmie upatrywał przyczyn przyszłości jednostki, a także naprawy bądź zguby państwa, narodu i świata. Według niego autodeterminizm powinien być poddany wymogom Bożym: „Najlepsze zaś są te możliwości każdej jednostki, które najdokładniej ja wyrażają jako taką, to znaczy te, które realizują to, co w niej jest najbardziej boskie, a przez to samo oryginalne, co nie jest plagiatem, imitacją" (JAKUBISIAK 1948, 230). W innym miejscu dodał z kolei: „Stąd wniosek stanowiący podstawową zasadę autodeterminizmu: przyszłości nie należy oczekiwać od układu wypadków zewnętrznych, ale od realizacji możliwości zawartych w jednostce ludzkiej" (JakUBisiak 1948,143). Podobnego zdania był Miciński w liście do Juliana Tuwima:

Stale popełnia się ten błąd, że usiłuje się pojmować życie psychiczne według czasowo-przestrzennych stosunków świata zewnętrznego. Obcując stale z krzesłami, z kanapami, zaczynamy pojmować życie wewnętrzne tak, jakby było „rozciągłe”, tzn. przestrzenne. A tymczasem to, co stosuje się do świata zewnętrznego, ça ne marche pas w życiu psychicznym. CZŁOWIEK JEST ZDETERMINOWANY WŁASNYMI PRAGNIENIAMI! JEST TO TAK ZWANY 'AUTODETERMINIZM' (vide ks. Augustyn Jakubisiak, 20 bis, rue Censier, Paris). Sam siebie determinuje celami, które stawia przed sobą: jeszcze nie zrealizowane w porządku czasowym cele, pragnienia, które cel postawiły, są już przyczyną działań, które do tych celów prowadzą. (Micí́sKi 1970, 458-459).

Cytat ten świadczy o tym, że również Miciński był przeciwnikiem monizmu i dziejowego determinizmu. W swych esejach filozoficznych i tekstach krytycznoliterackich pozostawił różne uwagi na temat wolności. Recenzując tom poetycki Kazimierza Wierzyńskiego Wolność tragiczna, zauważył: „Wolność zdobywamy za cenę własnowolnego ograniczenia się, za cenę «samookiełznania» - jesteśmy wolni, bo sami wykreślamy granice naszej wolności. Jest to «Wolność Heroiczna»" (Miciński 1970, 316). Miciński głosił zatem 
potrzebę „,przezwyciężania własnych autodeterminant”"14, aby uniknąć automatyzmu, czyli największego wroga twórczości. Do myśli ks. Jakubisiaka Miciński dodawał, że ,autodeterminizm dotyczy nie tylko jednostek, ale i narodów" (MiciŃSKI 1970, 173).

Ks. Jakubisiak uznawał za podstawowe czynności poznawcze „widzenie rozróżniające wielość i selekcję, która jest działem woli” (JAKUBISIAK 1936, 24). To bowiem wola kieruje uwagę intelektu na określony przedmiot, a następnie intelekt odróżnia poznany przedmiot od innych. Miciński ujmował to w następujący sposób w eseju $O$ nienawiści, okrucieństwie i abstrakcji:

Wchodzimy więc - jak się zdaje - w okres nowych rozgraniczeń. Może wolność stanie się różnicą gatunkową, „formą”, która różnić będzie człowieka od ludzi, podobnie jak mądrość, która wyodrębniła go ze świata zwierząt.

Człowiek nie jest z „natury” dobry, ani z „,natury” zły. Może stać się dobry i może stać się zły.

A więc - A vous de choisir — souscrivez aux bons d'armenent! - Souscrivez.

Aby przez wolność myśli rozwijać intelekt, aby przez wolność intelektu przezwyciężać determinizm. Aby przez zwyciężanie biologicznego determinizmu stworzyć podstawy pod optymistyczną ocenę jednostki - aby przezwyciężyć abstrakcję, okrucieństwo, nienawiść. (MicIŃSKI 1970, 147)

Konteksty wypowiedzi Micińskiego na temat jednostki i autodeterminizmu (a także słabiej zarysowane problemy czasu i przestrzeni) wskazują, że nie tylko przejmował od ks. Jakubisiaka istotne dla niego pojęcia, lecz także osadzał je w bliskim sobie kontekście światopoglądowym. Myśl polskiego duchownego musiała być dla Micińskiego podwójnie inspirująca. Po pierwsze, odkrywał w jego pracach znane sobie style filozofowania wywodzące się od św. Augustyna, Leibniza, Pascala czy Kanta. Z drugiej strony poszerzał pola własnych poszukiwań i znajdował odpowiedzi na istotne egzystencjalne pytania; zwracał się w kierunku współczesnej nauki (chociażby teorii Einsteina), a zwłaszcza chrześcijaństwa, które stawało się dla niego coraz ważniejszym intelektualnym i duchowym azylem ${ }^{15}$. Jak pod-

${ }^{14}$ List do Wacławostwa Grzybowskich (MiciŃSKi 1970, 469). Z kolei w jednym ze swych ostatnich listów z kwietnia 1943 r. adresowanym do Denise Bouchyer Miciński pisał: „In summa: - człowiek - przynajmniej w dużym stopniu, skoro nie chciałby Pani inaczej — jest twórca samego siebie. Rządzi nim determinizm celów, a nie przyczyn (Autodeterminizm, o którym będzie Pani zapewne dużo rozmawiała.) Tworzy siebie i może stać się własnym niewolnikiem. Nie wie nawet, kiedy od wewnątrz monada zasycha i przestaje być źródłem życia" (MICIŃSKI 1970, 513).

${ }^{15}$ Halina Micińska-Kenarowa przekazała informację, że Michał Spisak (skrzypek i kompozytor, który w 1942 r. zamieszkał z Micińskimi w Grenoble) „w Bouquéron podpatrzył, że na kartkach pisanych przez Bolka zawsze w prawym rogu były literki WB, czyli «W Imię Boże», tak zaczynał rankami pisanie" (MiciŃSKA-KeNAROwA 2003, 145). 
kreśla Konstanty Régamey, w ostatnim okresie życia Miciński „znajduje pociechę w religii, do której był głęboko przywiązany przez całe życie. W poczuciu tym umacnia go obecny przy nim do ostatniej chwili ks. Jakubisiak" (RÉGAMEY 1995, 41). Z relacji ks. Jakubisiaka wynika natomiast, że widział się z Micińskim pięć dni przed jego śmiercią. Musiał być więc bardzo zdeterminowany, aby dojechać do położonego wysoko w górach, trudno dostępnego Laffrey, gdzie na odludziu przebywał z rodziną umierający polski emigrant, który wówczas miał jedno pragnienie: „wytoczyć przyszłe linie naszych dróg...[...], jak genialny wizjoner z Patmos ujrzeć dzieje od razu [...] wyzwolić się z naszego czasu, rozszerzyć w nieskończoność krąg wąskiej świadomości i widzieć: «co dalej»” (JAKUBisiaK 1947, 32).

Ten, który - jak stwierdza ks. Jakubisiak - „z Pismem Świętym się nie rozstawał" (JAKUBISIAK 1947, 32), podjął jeszcze pod koniec życia wielkie problemy estetyczne i moralne. Niemiłosiernie trawiący go czas sprawił, że był filozofem i twórcą, który bardzo oszczędnie spisał to, co przemedytował. Dlatego tym bardziej jego myśl i dzieło zasługują na wyszukanie nieznanych tekstów pisarza, wytropienie kontekstów jego myśli i rozwinięcie niedokończonych wątków.

List Micińskiego znajduje się w Bibliotece Polskiej w Paryżu, w archiwum ks. Augustyna Jakubisiaka, a ściślej w zbiorze korespondencji (trudno było go znaleźć, ponieważ korespondencja jest nieuporządkowana). Nie ma daty (jak to często bywało w przypadku tego autora). Napisany jest na czterech gładkich, połączonych ze sobą stronach papieru kancelaryjnego, każda o wymiarach $27 \times 21 \mathrm{~cm}$. Zostały one zapisane dwustronnie niebieskim atramentem. List składa się z dwóch części przygotowanych w odstępie około trzech, czterech tygodni. Pierwsza część powstała wkrótce po przybyciu Micińskich do Montaigut, a więc na początku lutego 1940 r. Druga część została spisana trzy lub cztery tygodnie później, tzn. w pierwszej dekadzie marca 1940 r. Z pisma, które Miciński adresował do Stempowskiego 18 marca 1940 r., wynika, że niebawem po pierwszym liście do ks. Jakubisiaka z Montaigut wysłał kolejny, w którym prosił, aby ksiądz pomógł Stempowskiemu w uzyskaniu posady na uczelni w Paryżu. Wkrótce ks. Jakubisiak odwiedził Micińskich w Montaigut i obiecał, że będzie się starał o wizę francuską i pieniądze na drogę dla Stempowskiego, który $\mathrm{w}$ tym czasie przebywał w Bernie. 


\section{(List sprzed trzech tygodni)}

Ojcze ukochany! Jak dziękować za list i przepraszać za moje milczenie. Jak mi trudno pisać — zdaje mi się zawsze, że przecież Ojciec wszystko o nas wie. Najbardziej mnie martwi, że w pierwszym n-rze nie będzie naszego artykułu. Próbowałem pisać, ale dość nieoczekiwanie - zamiast art[tykułu] filozoficznego napisałem rzecz raczej publicystyczną ${ }^{1}$ raczej dla „Wiadomości” niż dla „Revue”. Ale tak się przełamały pierwsze trudności. Teraz potrzebę pisania mam tak wielką jak nigdy, a co najważniejsze dostanę prawdopodobnie część moich notatek z Warszawy. Trudno jest pisać w Montaigut zupełnie bez książek. Ten szkic, który wysłałem do „Wiadomości” to jakby dyspozycja i zaznaczenie tonacji tego art[ykułu], który chciałbym napisać dla „Revue”. Jeśli się to Ojcu spodoba, to będę wiedział czego się trzymać i rzecz rozwinę. Właściwie to nie powinienem się skarżyć na brak książek - nawet gdybym je miał, to i tak niewiele bym czytał. Powiedział mi Ojciec, żebym „wszedł w siebie”. I tak teraz jest. Jest to pierwszy chyba okres w moim życiu, kiedy moge powiedzieć, że na razie „wystarczam sam sobie” i ani książki mi są niepotrzebne, ani ludzie, bez których dawniej nie umiałem żyć. Nie jest to megalomania - raczej odwrotnie, bo trudno mi powiedzieć, żeby mi było zawsze z sobą dobrze. Myślę, że gdy[bym] mógł jednak wpaść na dzień dwa do Paryża i zobaczyć Ojca. Jest to moja jedyna osobista potrzeba.

Trudno powiedzieć jak mnie ucieszyła wiadomość o prof. Żółtowskim³ Myślałem o nim często z niepokojem szczególnie ostatnio. Znam tak mało, ale jest w nim delikatność i dobroć, które ujmują z miejsca. Dostałem znów list od Jerzego Stempowskiego — jest już w Szwajcarii i czeka na wizę.

Nasze życie układa się spokojnie i dobrze. Córeczka coraz ładniejsza. Przedziwnie spokojna. Nigdy jej nie słychać - ciągle się uśmiecha, bawi się grzechotką. Nela ${ }^{4}$ ślicznie gospodaruje i ma jeszcze sporo czasu dla siebie (tłumaczy Ch. Péguy). Halusia ${ }^{5}$ jak zawsze jest dla mnie oparciem.

Ojcze ukochany! Oto list, który zacząłem pisać przed miesiącem. Nie wysyłałem, bo zawsze mi się zdawało, że potrafię napisać coś mądrego 
w liście i nic z tego nie wychodzi. Doprawdy nie jestem epistolografem! A szczególnie tak trudno pisać do Ojca. Kiedy tak jest - tak jest w istocie - kiedy ani na chwile od Ojca myślami nie odchodzę. Kiedy siadam do pisania listu, mam wrażenie, że pisze do Kogoś, kto jest w sąsiednim pokoju i z kim przed chwilą właśnie rozmawiałem.

Ostatnie wydarzenia jak wszystkich zresztą i każdy dzień jest ciężki. Ale ja wierzę, tak wierzę w zupełne zwycięstwo.

Nela przed paru dniami dostała wiadomość, że jej „sympatia” - [...] leży ranny $w$ szpitalu, zdobyła sauf-conduit ${ }^{6}$ i pojechała. Coraz więcej też uchodźców i nie bez podstaw - zdaje się — obawiam się, żeby to nie pociągnęło za sobą kłopotów, które mogłyby nas bezpośrednio dotknąć. W związku z tym chciałbym bardzo mieć jakieś zaświadczenie od Uniwersytetu Polskiego w Paryżu. W Warszawie byłem starszym asystentem, tu, zdaje się, także jestem wpisany na listę - jakaś legitymacja Uniwersytecka, albo coś w tym rodzaju, coś, co stwierdzałoby mój związek z Uniwersytetem, bardzo byłoby dla mnie ważne. Gdyby Ojciec mógł uzyskać dla mnie taki papierek! Nie chodzi mi tu o legitymację studencką, ale o jakieś zaświadczenie, które przedstawiałoby mnie jako „digne de confiance”" Myśleć teraz i pisać o sprawach — ostatecznie „osobistych" to prawie nieprzyzwoitość, ale ja muszę myśleć nie tylko o sobie, ale i o Halusi i o dziecku. Moja sytuacja człowieka „bez pracy” jest dość głupia, ale ja naprawdę pracować nie mogę. Byłem ostatnio badany w Sanatorium i stwierdzono „Tuberculose pulmonaire fibrocaséeuse bilaterale excavée, avec bacilloscopie positive" ${ }^{8}$ [gruźlica płucna włóknisto dwustronnie wydobyta z pozytywną]. Dlatego nie tylko, że ani pracy, ani trudniejszych warunków klimatycznych znieść bym nie mógł, chciałbym mieć takie świadectwo Uniwersyt[eckie], które ułatwiłoby mi tu życie w „spokoju”. Słowo w „spokoju” jest również i dziś śmieszne jak nieprzyzwoite i dlatego ująłem to w cudzysłów.

Gdybym wiedział, że Ojciec był w Vichy, zaraz byśmy tam przyjechali trudno powiedzieć jak tęskno. Cokolwiek by było, proszę pamiętać, że my zawsze czekamy, że czeka Ojca „Jego” pokój u nas.

Wszystkimi myślami - zawsze cały jestem przy Ojcu. Proszę mi darować, że listy moje takie do niczego. Ręce Ojca całuję — oddany — najwierniejszy 
${ }^{1}$ Chodzi o szkic O nienawiści, okrucieństwie $i$ abstrakcji, który ukazał się w „Wiadomościach Polskich Politycznych i Literackich", Londyn 1940 nr 10, s.3.

${ }^{2}$ Prawdopodobnie chodzi o Revue néo-scolastique de philosophie — pismo założone w $1894 \mathrm{r}$. przez Desiré Merciera pod nazwą Revue néo-scolastique

${ }^{3}$ Adam Żółtowski (1881-1959) - profesor filozofii i polityk narodowy w II RP. W latach 1920-1933 był kierownikiem Katedry Filozofii Nowożytnej w Uniwersytecie Poznańskiem, a od 1950 do 1959 r. profesorem PUNO. Opublikował m.in.: Graf August Cieszkowski's „Philosophie der Tat” (1904), O postawach filozofii Hegla (1907), Filozofia Kanta. Jej dogmaty, zludzenia, zdobycze (1923), Descartes (1937), Zarys historii filozofii (1952).

${ }^{4}$ Aniela Micińska (1908-1992) - siostra B. Micińskiego, która mieszkała razem z nim, jego żoną i córką we Francji. Po wojnie wyszła za Zbigniewa Ulatowskiego. Była tłumaczką literatury francuskiej.

${ }^{5}$ Helena Micińska, z d. Krauzowa, s.v. Kenarowa (1915-1998) — żona B. Micińskiego. Pedagog, krytyk, thumacz. Zdała maturę w Grodnie, a następnie studiowała romanistykę na Uniwersytecie Warszawskim. Po wojnie mieszkała z Zakopanem, gdzie była dyrektorką Szkoły Przemysłu Drzewnego zwanej Szkołą Kenara.

${ }^{6}$ List żelazny (fr.)

${ }^{7}$ Godna zaufania (fr.)

${ }^{8}$ Gruźlica płucna zwłóknieniowa, przebiegająca obustronnie, z dodatnim wynikiem badania bakterioskopowego.

\section{REFERENCJE}

Ambrożewicz, Zbigniew. 2003. Esej filozoficzny Bolesława Micińskiego jako sposób poszukiwania podstaw realności świata. Opole: Wydawnictwo Uniwersytetu Opolskiego.

GaŁęzowska, Irena. 1947. Ksiadz Augustyn Jakubisiak. Paryż: Biblioteka Polska i Towarzystwo Historyczno-Literackie.

JAKUBISIAK, Augustyn. 1946. Wytrwać by zwyciężyć. Zbiór odczytów i przemówień 1940-1945. Paryż: S.G.I.E.

JAKUBISIAK, Augustyn. [b.r.w. - 1928?]. O granicach przestrzeni i czasu. Przełożył Zygmunt Jakimiak, mps, akcesja 3420, pudło 1, Archiwum A. Jakubisiaka. Paryż: Biblioteka Polska w Paryżu.

JAKUBISIAK, Augustyn. 1936. La pensée et le libre arbitre. Paris: Libraire J. Vrin.

JaKUBISIAK, Augustyn. 1947. Stowo wstępne X. Augustyna Jakubsiaka. Rzym.

Jakubisiak, Augustyn. 1948. Nowe Przymierze. Z zagadnień etyki. Paryż. Komitet Wydawniczy Dzieł Księdza Augustyna Jakubisiaka.

Krauzowa, Zofia. 1979. Rzeki mojego życia. Kraków: Wydawnictwo Literackie.

KrZYCH, Bartłomiej K. 2018. „Ksiądz Augustyn Jakubisiak — słowo o zapomnianym polskim myślicielu i badaniach nad jego spuścizną". Wschodni Rocznik Humanistyczny nr 1: $113-125$.

MicińsKa-Kenarowa, Halina. 1995. „O Jerzym Stempowskim (1893-1969). W: Bolesław MiCIŃSKI, Jerzy STEMPOwSKi. Listy. Opracowanie Anna Micińska, Jarosław Klejnocki, Andrzej Stanisław Kowalczyk. Wprowadzenie Halina Micińska-Kenarowa, Konstanty Régamey, Warszawa: Wydawnictwo „Więź”. 
Micińska-Kenarowa, Halina. 2003. Długi wdzięczności. Słowo wstępne Czesław Miłosz. Warszawa: Wydawnictwo Więź.

Miciński, Bolesław. 1937. Rzeczywistość i jej deformacja w sztuce. Warszawa: Archiwum Uniwersytetu Warszawskiego, mps.

Miciński, Bolesław. 1947. Portret Kanta i trzy esseye o wojnie. Rzym: Instytut Literacki.

Miciński, Bolesław. 1970. Pisma. Eseje, artykuły, listy. Kraków: Wydawnictwo Znak.

Miciński, Bolesław, i Jerzy Stempowski. 1995. Listy. Opracowanie Anna Micińska, Jarosław Klejnocki, Andrzej Stanisław Kowalczyk. Wprowadzenie Halina Micińska-Kenarowa, Konstanty Régamey. Warszawa: Wydawnictwo „Więź”.

RÉGAmey, Konstanty. 1995. Bolesław Miciński (1911-1943). W: Bolesław Miciński, Jerzy StemPOwsKi, Listy. Opracowanie Listy. Opracowanie Anna Micińska, Jarosław Klejnocki, Andrzej Stanisław Kowalczyk. Wprowadzenie Halina Micińska-Kenarowa, Konstanty Régamey. Warszawa: Wydawnictwo „Więź”.

TAtarkiewicz, Władysław. 1977. „O Bolesławie Micińskim”. W: 70 żywotów. Wybrał i zredagował Andrzej Paluchowski, przedmową opatrzył Jerzy Turowicz. Kraków: Wydawnictwo Znak.

ŻóŁtowski, Adam.1904. Graf August Cieszkowski's „Philosophie der Tat”. Posen.

ŻóŁtowsKi, Adam. 1907. O postawach filozofii Hegla. Kraków: Wydawnictwo Akademii Umiejętności.

ŻóŁtowski, Adam. 1923. Filozofia Kanta. Jej dogmaty, złudzenia, zdobycze. Poznań: Poznańskie Towarzystwo Przyjaciół Nauk.

Żółtowski, Adam.1937. Descartes. Poznań: Poznańskie Towarzystwo Przyjaciół Nauk.

ŻóŁtowski, Adam. 1952. Zarys historii filozofii. Londyn: Polski Uniwersytet na Obczyźnie.

\section{FILOZOF DO FILOZOFA. \\ WOKÓŁ LISTU BOLESŁAWA MICIŃSKIEGO \\ DO KS. AUGUSTYNA JAKUBISIAKA}

\section{Streszczenie}

W artykule zaprezentowano nieznany list Bolesława Micińskiego do ks. Augustyna Jakubisiaka znaleziony $\mathrm{w}$ jego archiwum w Bibliotece Polskiej w Paryżu. Jest to okazja do przypomnienia tych wybitnych, choć nieco zapomnianych filozofów oraz do prezentacji ich powiązań intelektualnych. Poznali się w 1937 r. w Paryżu i odtąd utrzymywali bliskie kontakty, aż do śmierci Micińskiego w 1943 r. Od początku łączył ich sprzeciw wobec idealistycznej filozofii niemieckiej oraz neopozytywizmu Koła Wiedeńskiego z jego materializmem, scjentyzmem i sceptycyzmem. Miciński odkrywał u ks. Jakubisiaka bliskie sobie poglądy na temat przestrzeni i czasu. W ostatnich esejach Micińskiego z okresu wojny pojawiają się tezy o charakterze moralnym, które głosił ks. Jakubisiak, a mianowicie jednostkowość i autodeterminizm. Jednostkowość oznacza dowartościowanie jednostki w obliczu wszystkiego, co może jej zagrażać, zwłaszcza totalizmów. Z kolei autodeterminizm to przyznanie ludzkiemu bytowi absolutnej autonomii i wolności, która działa w przyjętym uprzednio kierunku. Było to zanegowanie determinizmu i ateizmu. Konteksty wypowiedzi Micińskiego na temat jednostki i autodeterminizmu (a także słabiej zarysowane problemy czasu i przestrzeni) wskazują, że nie tylko przejął on od Jakubisiaka istotne dla niego pojęcia, lecz także osadził je w bliskim sobie kontekście światopoglądowym. Myśl polskiego duchownego musiała być dla Micińskiego podwójnie inspirująca. Po pierwsze, 
odkrywał w jego pracach znane sobie style filozofowania wywodzące się od św. Augustyna, Leibniza, Pascala czy Kanta. Z drugiej strony poszerzał pola własnych poszukiwań i znajdował odpowiedzi na istotne egzystencjalne pytania; zwracał się w kierunku współczesnej nauki (chociażby teorii Einsteina), a zwłaszcza chrześcijaństwa, które stawało się dla niego coraz ważniejszym intelektualnym i duchowym azylem.

Słowa kluczowe: Bolesław Miciński; Augustyn Jakubisiak; jednostkowość; autodeterminizm; historia filozofii polskiej; idealizm niemiecki; totalitaryzm.

\section{PHILOSOPHER TO PHILOSOPHER: REGARDING A LETTER BY BOLESŁAW MICIŃSKI TO FR. AUGUSTYN JAKUBISIAK}

\section{Sum mary}

The article presents an unknown letter by Bolesław Miciński to Fr. Augustyn Jakubisiak found in his archives at the Polish Library in Paris. It is an opportunity to call to mind these outstanding but somewhat forgotten philosophers and to present their intellectual connections. After meeting in Paris in 1937, they maintained close contact until the death of Miciński in 1943. From the beginning, they were united by their opposition to the idealistic German philosophy and neopositivism of the Vienna Circle with its materialism, scientism and scepticism. In Fr. Jakubisiak, Miciński discovered views similar to his own on space and time. In Miciński's recent essays from the war, there are moral theses that Fr. Jakubisiak has voiced, namely individuality and self-determination. Individuality means valuing an individual in the face of everything that may threaten him, especially totalitarianism. In turn, self-determination is the granting of absolute autonomy and freedom to human beings, which acts in the previously adopted way. It was the negation of determinism and atheism. The contexts of Miciński's statements on the subject of individuality and self-determination (as well as the less outlined problems of time and space) indicate that he not only took from Fr. Jakubisiak the concepts relevant to him, but also embedded them in a close philosophical context. The thought of a Polish clergyman must have been doubly inspirational for Miciński. First, he discovered in his works known philosophizing styles derived from St Augustine, Leibniz, Pascal or Kant. On the other hand, he expanded his own search field and found answers to relevant existential questions; he turned towards modern science (for instance Einstein's theory), and especially to Christianity, which became for him an increasingly important intellectual and spiritual asylum.

Keywords: Bolesław Miciński; Augustyn Jakubisiak; individuality; self-determination; history of Polish philosophy; German idealism; totalitarianism.

Information about Author: Prof. Dr. habil. Ryszard ZAJĄCZKowsKi - The John Paul II Catholic University of Lublin, Faculty of Philosophy, Department of History of Polish Philosophy; address for correspondence: Al. Racławickie 14, 20-950 Lublin, e-mail: rzajac@kul.pl; ORCID: https://orcid.org/0000-0003-3417-3666. 